Digital Press Social Sciences and Humanities

Potential Object Mapping of Nagari Batuhampar Religious Tourism Destination for Sustainable Development in Limapuluh Kota District

Bigharta Bekti Susetyo, Rery Novio, Widya Prarikeslan, Widia Sutriani and Feri Ferdian

Proceeding of The Non-Formal Education International Conference 2020

Alim Harun Pamungkas, Jamaris, Solfema (eds) 


\title{
Potential Object Mapping of Nagari Batuhampar Religious Tourism Destination for Sustainable Development in Limapuluh Kota District
}

\author{
Bigharta Bekti Susetyo*, Rery Novio, Widya Prarikeslan, Widia Sutriani, Feri Ferdian \\ Department of Geography, Faculty of Social Science, Universitas Negeri Padang, Indonesia \\ *e-mail: bighartabekti@fis.unp.ac.id
}

\begin{abstract}
Nagari Batuhampar is a village located in Akabiluru District, Limapuluh Kota Regency. Nagari Batuhampar has physical and social potential that can be used as a tourist destination. This has been planned in the Nagari Strategic Plan which will develop tourism in the form of religious tourism. However, the problem in the field is that there is no map as a reference for regional development. The Nagari government views the importance of making this map as an aspect of regional development decision making. This research is classified as a descriptive quantitative survey research, which explains the phenomena in the field in accordance with the original situation. The purpose of this study is to map the location of the objects of religious tourism destinations in Nagari Batuhampar. This is intended so that the development of tourism-based areas is more monitored, mapped, planned, and evaluated. The result of the research states that the tourism object location points are along the road. This can be developed later to diversify attractions between tourism locations.
\end{abstract}

\section{Keywords}

mapping, Nagari Batuhampar, tourism destination objects

\section{Introduction}

Tourism at this time is one of the options to increase regional economic development. According to data, tourism in West Sumatra is increasing (Badan Pusat Statistik Kabupaten Solok, 2020). The circulation of money circulating in the area of tourism destination objects (ODTW) can improve the welfare of the surrounding community. Some examples are buying and selling activities, services, lodging, creative industries that can rotate the supply and demand of commodities. Souvenirs such as Sanjay chips, cassava raw materials (from farmers), plastic packaging (industry/UMKM), printing (services), and transportation, this kind of trickle-down effect is expected by tourism activities (Sumarmi, 2012). However, not all regions have great opportunity/potential as ODTW. Problems can occur in physical, social, policy, and potential aspects that have not been comprehensively mapped/developed, even though in West Sumatra many areas have good tourism potential such as Mandeh one of KSPN (National Tourism Strategic Areas) (Biro Komunikasi Publik Kementerian PUPR, n.d.).

Nagari Batuhampar is one of the Nagari in Akabiliru District, Limapuluh Kota Regency. This Nagari has a strategic location between Bukittinggi-Pekanbaru which is busy with private vehicles, commerce, and so on. Some objects in Nagari Batuhampar have potential as ODTW which can be developed into culturalreligious based tourism. The old mosque, the minaret, the tomb of the hero (Bung Hatta's father), the pondok/surau, and the beautiful natural environment should have the potential to be developed. Based on an interview (2020) with Mr. Wali Nagari Batuhampar, Romi Suhardi, A.md, the village has attempted tourism activities by forming a Pokdarwis (Tourism Awareness Group) but there are no details on how to map and monitor potential.

Geographical Information System is an assistive science in the field of Geography which basically has components such as Users, Hardware, Software, Methods, and Data. Has a function as monitoring, mapping, measurement, modeling, and management (Paramasivam, 2019). This can be used in almost all fields, including tourism activities. Initial data input such as data on tourist location points, data processing until the output is a map in accordance with the research theme. Obstacles in mapping the 
distribution of ODTW in Nagari Batuhampar can be assisted by a geographic information system by paying attention to mapping and research principles.

\section{Methods}

This research is classified as a quantitative descriptive survey. The results of the study explain the real conditions in the field. Mapping techniques use GPS (Global Positioning System) sampling, remote sensing and interviews. Point samples are required for photo tagging of tourist destinations (ODTW) Nagari Batuhampar. Remote sensing to see the terrain in the field and supported by interviews as primary data and supporting descriptions. ArcGIS 10.4.1, Google Earth, and QGIS applications were used to map the ODTW Nagari Batuhampar.

\section{Results and Discussion}

Nagari Batuhampar can be accessed via several main roads/arteries, access from Bukittinggi, and from Pekanbaru Riau. After that, ODTW can be reached into the Nagari road approximately 300 meters with two four-wheeled lanes passing by each other. Good road access is paved, but traffic signs/tourist directions are not yet adequate. Some of the identified ODTW distributions are:

Table 1 ODTW and Description

\begin{tabular}{|c|c|c|}
\hline No & ODTW & Description \\
\hline 1 & $\begin{array}{l}\text { Old } \\
\text { Mosque }\end{array}$ & $\begin{array}{l}\text { The mosque was built in 1929, with a red brick structure. According to Mr. Walinagari, Romi Suhardi, } \\
\text { A.md, the mosque is a symbol and a reminder of many religious leaders who were born in Nagari } \\
\text { Batuhampar. }\end{array}$ \\
\hline 2 & $\begin{array}{l}\text { Mosque } \\
\text { minaret }\end{array}$ & $\begin{array}{l}\text { The tower for the call to prayer, } 1929 \text { with a unique building shape and a red brick structure. The } \\
\text { tower is approximately } 8-12 \text { meters high with several doors and windows. On the inside, there are } \\
\text { stairs that can be used to reach the top of the tower. }\end{array}$ \\
\hline 3 & $\begin{array}{l}\text { Heroes' } \\
\text { Tomb }\end{array}$ & $\begin{array}{l}\text { The grave of the heroes of Nagari Batuhampar, one of which is the tomb of the father of the } \\
\text { proclamator Bung Hatta, Syekh Muhammad Jamil Bin Abdul Rahman. It proves that the religious } \\
\text { scholars and clever people in Nagari Batuhampar have been famous for a long time. Nagari } \\
\text { Batuhampar also has Prof. Mestika Zed as one of the national historical figures }\end{array}$ \\
\hline 4 & Surau & $\begin{array}{l}\text { Cultural activities of Minangkabau boys reciting and studying in the surau. This culture has almost } \\
\text { disappeared because young people are less and less involved in this activity. In fact, through tourism } \\
\text { activities, Ninik Mamak and Alim Ulama Dt Rajo Bagindo support tourism to be developed with the } \\
\text { hope that Minangkabau cultural values can be maintained and sustainable. }\end{array}$ \\
\hline 5 & $\begin{array}{l}\text { Natural } \\
\text { Rice } \\
\text { Fields }\end{array}$ & $\begin{array}{l}\text { Beautiful Batuhampar Nagari Street with green views of rice fields. This can be developed as an } \\
\text { alternative to the cycling route. }\end{array}$ \\
\hline
\end{tabular}

The data in Table $\mathbf{1}$ is used as prefix data and then GPS data is collected based on KML (keyhole markup language). KML data is one of the data inputs in GIS, besides that, it is supported by administrative map data with a scale of 1: 5000 and other attribute data such as rivers, roads, administrative boundaries and so on which are taken from Podes data (village potential). The next stage is processing the data in the geographic information system then the output is a map of the ODTW distribution in Nagari Batuhampar with photo tagging of the field results. 


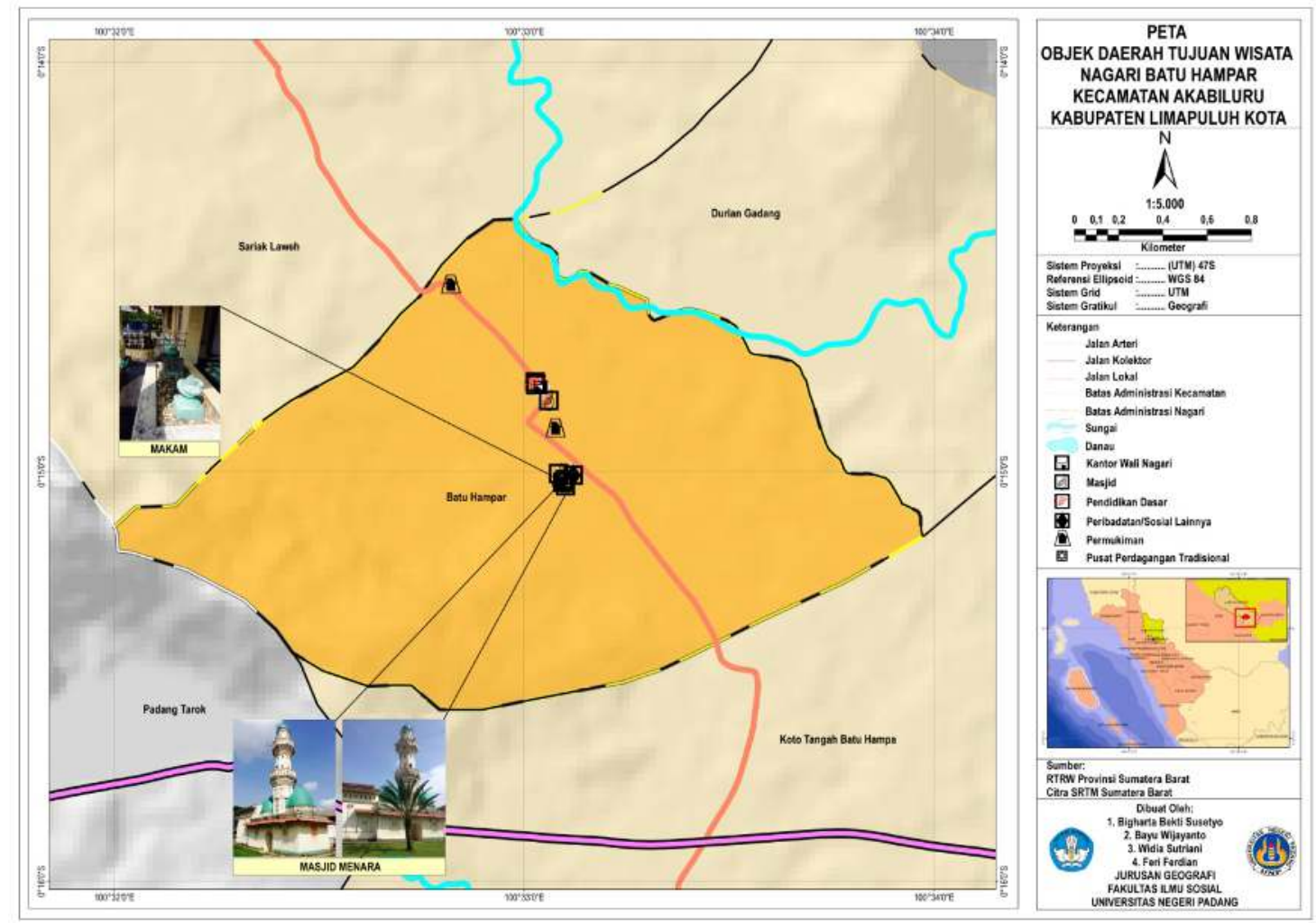

Fig. 1 Map of The Distribution of Tourism Objects in Nagari Batuhampar

Based on the map above, several ODTWs are scattered along the Nagari road. Access roads that are paved with good conditions, four wheels can pass by. This map also shows the route for tourists who want to visit Batuhampar Nagari. ODTW is not far from the Bukittinggi-Pekanbaru route, it is hoped that the community can visit and tour this place.

Tourism is an activity that has a broad impact on society. Social, economy, culture can develop dynamically because of tourism (Byrd, 2007). Even the cultural aspects in other examples can be dynamically developed and sustainable, sustainably maintained by the community. So, it is not an exaggeration that tourism activities can preserve cultural customs values as long as the community can filter out the negative effects of tourism and always develop positive values.

\section{Conclusions}

The tourist objects which are located in Nagari Batuhampar are located along the road and are not spread far away. Some of the objects include the Old Mosque, the Minaret of the Mosque, the Tomb of Heroes, and Pondok Culture with its surau and the natural environment of beautiful green rice fields. Based on this, the existing tourism potential is related to culture and religion. It is necessary to have a Nagari Batuhampar policy which is the basis for developing this tourism potential, community involvement as social capital in supporting tourism development is also needed.

\section{References}

Badan Pusat Statistik Kabupaten Solok. (2020). Perkembangan Pariwisata dan Transportasi Sumatera Barat Desember 2019. Retrieved from https://solokkab.bps.go.id/pressrelease/2020/02/04/494/perkembanganpariwisata-dan-transportasi-sumatera-barat-desember-2019.html

Biro Komunikasi Publik Kementerian PUPR. (n.d.). Kementerian PUPR Rampungkan 41,08 Km Jalan Akses Kawasan Wisata Mandeh. Retrieved from https://eppid.pu.go.id/page/kilas_berita/1053/KementerianPUPR-Rampungkan-41-08-Km-Jalan-Akses-Kawasan-Wisata-Mandeh 
Byrd, E. T. (2007). Stakeholders in sustainable tourism development and their roles: applying stakeholder theory to sustainable tourism development. Tourism Review, 62(2), 6-13. https://doi.org/10.1108/16605370780000309

Paramasivam, C. R. (2019). Merits and Demerits of GIS and Geostatistical Techniques. In GIS and Geostatistical Techniques for Groundwater Science (pp. 17-21). https://doi.org/10.1016/B978-0-12815413-7.00002-X

Sumarmi. (2012). Pembangunan Wilayah Berkelanjutan. Malang: Aditya Media. 